\title{
SANTAS, CONDENADAS OU DEMONÍACAS? MULHERES NO IMAGINÁRIO DO ALÉM-MUNDO NO CRISTIANISMO PRIMITIVO
}

\author{
Carlos Eduardo de Araújo de Mattos* \\ Paulo Augusto de Souza Nogueira**
}

\section{RESUMO}

Este artigo surge a partir de debates sobre a religião de mulheres no Cristianismo Primitivo. Enquanto se discute o papel de lideranças, apóstolas e mulheres mártires, optamos por enfatizar a presença feminina no Além-Mundo. Após apresentar as fonte e alguns comentários explicativos da mesma, destaco nelas (Apocalipse de Paulo, Apocalipse de Pedro e Atos Apócrifos de Felipe) como as mulheres consideradas pecadoras condenadas ao Inferno são retratadas e por quais pecados são punidas. Posteriormente, a partir de uma hermenêutica feminista de Tina Pippin, discuto o tema do tratamento geral que é dado às mulheres na literatura apocalíptica.

Palavras-chave: Apocalíptica; Religião de mulheres; Além-mundo.

\section{HOLY, DAMNED OR DEMONIC? WOMEN IN THE IMAGINARY FROM} BEYOND-WORLD IN PRIMITIVE CHRISTIANITY

\section{ABSTRACT}

This essay rises from discussions about the women's religions practices in Early Christianity. While so much is studied about the women in leadership, acting as apostles and martyrs, this essay propose to look for the female presence on the Other-World. After showing the sources and some commentaries about it, we highlight on this, (Visio Pauli, Apocalypse of Peter and Apocryphal Acts of Filip) how women treated as sinners and fated to Hell are represented and for wich

* Doutorando e Mestre em Ciências da Religião pelo PPG-CR na Universidade Metodista de São Paulo/CAPES. Endereço eletrônico: edubadofe@yahoo.com.br

** Doutor em Ciências da Religião e História e professor no Programa de Pós-Graduação em Ciência da Religião da Pontifícia Universidade Católica de Campinas.

Endereço eletrônico: pasn77@gmail.com 
sins those women are punished. Then, from feminist hermeneutics of Tina Pippin, we discuss the theme of general treatment received by women in the Apocaliptic Literature.

Keywords: Apocaliptc; Religion of women; Beyond world.

\section{¿SANTA, MALDITA O DEMONIACA? MUJERES EN LA IMAGINARIA MÁS ALLÁ-MUNDO EN CRISTIANISMO PRIMITIVO}

\section{RESUMEN}

Este artículo surge de debates sobre la religión de las mujeres en el cristianismo primitivo. Mientras discutíamos el papel de los líderes, apóstoles y mujeres mártires, elegimos enfatizar la presencia femenina en el Allá- Mundo. Después de presentar la fuente y algunos comentarios explicativos al respecto, destaco en ella (Apocalipsis de Pablo, Apocalipsis de Pietro y Actos Apócryfos de Filip) cómo se retratan las mujeres consideradas pecadores condenados al Infierno y por qué se castigan los pecados. Más tarde, de una hermenéutica feminista de Tina Pippin, discuto el tema del tratamiento general que se le da a las mujeres en la literatura apocalíptica.

Palabras clave: Apocalíptica. Religión de mujeres. Allá-mundo.

\section{INTRODUÇÃO}

Quem tem medo do Grande Deus Malvado?' O medo apocalíptico produz no Cristianismo Primitivo um Deus, grande criador de monstros que apavoram e levam seus seguidores a uma decisão: que lado escoIher na grande guerra entre o bem e o mal. Acontece que, diante dessa escolha, Deus é também um monstro e se revela tão perigoso quanto seus inimigos. Se não for mais.

Nesse contexto do Todo Poderoso que destrói implacavelmente seus inimigos, surgem, como fortes argumentos, textos de viagens ao Além, com uma mensagem bem clara: quem escolher o outro lado, enfrentará o destino dos pecadores, sofrendo penas terríveis por toda a eternidade. A curiosidade pelas condenações desses inimigos de Deus ganha um teor mais específico no recorte deste artigo: qual o papel representado pelas mulheres nesse quadro? A mulher é vista entre os

Este é o título do capítulo 7 da obra de Tina Pippin (Corpos Apocalípticos). O tema do capítulo é o medo apocalíptico. 
santos salvos, no Céu ou pecadoras condenadas, no Inferno? Estas são algumas das perguntas motivadoras.

Para responder estas perguntas e enfatizar a presença feminina nas descrições do Além, como elementos retóricos de posicionamento do Cristianismo Primitivo (CP) sobre os perigos representados pelas mulheres, escolhi fazer breves apresentações das três principais e mais antigas fontes cristãs dos primeiros séculos, em que surgem descrições do Inferno: Apocalipse de Paulo (Visio Pauli, VP), Apocalipse de Pedro (ApPe) e Atos Apócrifos de Felipe (AF). A seguir, faço uma breve apresentação dos três textos e comento cada uma delas, destacando os textos em que a presença feminina é marcada, separadamente. O motivo da escolha é pelo fato dessas três fontes trazerem as mais antigas descrições do Além-Mundo no CP.

\section{ASPECTOS RELEVANTES DA OBRA ATOS APÓCRIFOS DE FELIPE}

Os Atos Apócrifos de Felipe (AF a partir de agora) segue o roteiro do gênero a que pertence: Ata apostólica. Apresenta as aventuras de um apóstolo designado por Cristo para levar o evangelho a uma terra perigosa (Hierápoles da Frígia), enfrentando perigos, monstros e fazendo milagres, ganhando a simpatia de parte da população, causando desconforto e recebendo hostilidade por parte das autoridades religiosas e pessoas importantes do lugar, culminando no martírio do Apóstolo.

Os AF merecem atenção neste artigo porque no primeiro ato de Felipe ao chegar à Hierápoles, ele é abordado por uma viúva que conduzia o enterro de seu filho único e lamenta porque todos os sacrifícios e oferendas que fez a um panteão de deuses romanos e gregos foi em vão, pois nada foi capaz de salvar seu único filho de morrer. Felipe então, conversa com a mulher sobre temas presentes na maioria dos Atos Apócrifos (abstinência de comer determinados tipos de comida e encratismo) e se dirige ao morto, ordenando que ele volte à vida. Ao ressuscitar, o jovem começa a descrever o Inferno, afirmando que as pessoas devem renunciar a determinadas práticas para evitarem irem para aquele lugar. Antes de mencionar as partes que interessam a este artigo sobre este ato 1 , destaco aspectos importantes sobre a obra. 


\section{ATOS APÓCRIFOS DE FELIPE}

Piñeiro afirma que os AF que dispomos na atualidade, são compostos a partir do trabalho de três autores que juntos, trazem a totalidade atual de que dispomos para ler o texto. C Tischendorf editou o Ato 2 em 1850 servindo-se do manuscrito grego 881 de Paris. M. Bonnet publicou os Atos de Felipe na edição de Atos Apócrifos utilizando-se de diversos manuscritos (Antonio PIÑEIRO, 2011, p 6). Desses, temos para a parte que analisaremos a seguir, especificamente, o Ato $1 \mathrm{~V}$ : Vaticano Grego 824, século XI. A pesquisa localiza os AF aproximadamente ao final do século $4 \mathrm{EC}$, embora se discuta entre o final do século 3 e até inícios do século $5 \mathrm{EC}$. Neste sentido, sigo a datação de Piñeiro, que acredita que a obra seja do século 4 EC.

Para Piñeiro, o ato 1 nos manuscritos $V$ é um dos textos mais completos dos AF. Este texto, segundo Piñeiro, é comum aos manuscritos denominados como V, Vaticano 824 e em A Xenofontes 32 sendo aquele mais breve, embora o autor aponte que a primeira parte, da ressurreição do filho da viúva, é comum às duas fontes. Então, o que temos é um texto comum às duas fontes.

Segundo Piñeiro, as diferenças e contrastes em todo o texto dos AF se explicam melhor se a obra for pensada como um conjunto de textos diferentes, unidos em torno de um mesmo protagonista e provenientes de diferentes tradições. (Antonio PIÑEIRO, 2011, P 10)

$O$ Ato 1 dos AF merecem um destaque importante porque apresentam o que considero um "apocalipse fora de lugar". No início de um ato apostólico, que no geral, apresenta conteúdos semelhantes a tantos outros, o CP escolheu inserir um texto de descrição do inferno. Isso não é comum para os atos apostólicos apócrifos, embora o gênero apocalíptico seja bastante popular nesse período. A seguir, volto o foco do artigo para o tema central: observar a presença feminina no Inferno dos AF.

\section{AS MULHERES NO INFERNO DOS AF}

As mulheres cumprem papéis importantes na maioria dos Atos Apostólicos Apócrifos em geral. Sejam como seguidoras dos apóstolos e até mesmo, patrocinadoras de suas missões ou alvos dos milagres pra- 
ticados por eles ou companheiras de missão. Neste artigo, entretanto, desejo destacar a presença das mulheres nas descrições de Inferno das três fontes que escolhi como recorte. A descrição do Inferno de Felipe, no Ato 1 se abre com uma mulher em destaque:

[ l A 5]. 1. Vi uma mulher cujo aspecto era semelhante a um dragão e cujas mãos eram como dardos ao modo de línguas de áspides. Tinha um garfo ardente com o qual empurrava as almas dos homens a um abismo de fogo. Eu perguntei ao anjo: - Quem é esta mulher ?

Ele me respondeu:

- Esta mulher sugere aos homens que enganem aos crentes e zombem deles. Sugere a eles que digam que Cristo é um impostor e os conduz a este abismo. Os faz caluniar uns aos outros. Os que empurra com seu garfo e os engana para que façam palhaçadas e deste modo vão para a sua perdição. (Antonio PIÑEIRO, 2011, p 23)

A primeira mulher no Inferno dos AF é um demônio, com aspecto semelhante a um dragão, que empurra "as almas dos homens" ao abismo. É importante o destaque, pois, o texto não afirma que esta mulher em forma de demônio empurra as almas das pessoas, mas as almas dos homens. Esse recurso retórico pode significar muitas cosias, entre elas, que o poder demoníaco essencial deste demônio é seduzir aos homens. O fato do aspecto desta mulher ser como do dragão é relevante para os AF pois o apóstolo está em Hierápoles, destacada na obra como a terra das serpentes e, em muitos outros trechos, essas serpentes serem confundidas com dragões. Um dos atos da obra apresenta o encontro de Felipe com outro demônio em forma de dragão que era mãe de serpentes que protegiam a cidade. Depois deste primeiro encontro, a descrição do jovem que foi ressuscitado por Felipe segue, sem apresentar mais figuras femininas entre as condenadas, exceto por uma cena próxima ao final do quadro de descrição do Inferno, quando o jovem, ao se aproximar da saída do Inferno vê um homem e uma mulher devorados por Cérbero, cachorro de três cabeças da mitologia grega, que guarda as portas de saída do Inferno: 
[ I A 12]. 1 Quando ouvi estas coisas, me apressei a sair uma vez fora, vi diante da porta um homem e uma mulher . o grande cachorro chamado Cerbero, o de três cabeças, estava preso na porta com cadeias de fogo e devorava ao homem e a mulher, sujeitando entre as patas os fígados de ambos. Eles, como meio mortos, gritavam:

- Tenha piedade de nós, ajude-nos!

E ninguém os ajudava. Eu corri para os pegar de volta do cão, mas me disse Miguel:

- Deixa-os, porque eles também blasfemaram contra os presbíteros, as presbíteras, os eunucos, os diáconos, as diaconisas, as virgens, acusando-os falsamente de libertinagem e adultério. (Antonio PIÑEIRO, 2011, p 27).

Nesta cena, vemos uma mulher condenada, junto com um homem, por blasfemar e acusar autoridades eclesiásticas e virgens, de libertinagem e adultério.

Depois de descrever e destacas as presenças femininas nas duas fontes que se seguem para este artigo, analisaremos mais a fundo as condenações e penas que as mulheres condenadas ao Inferno pagam. No caso específico dos AF, as duas mulheres presentes no Inferno estão relacionadas ao pecado de blasfêmia: uma, em forma de demônio, induz os homens a blasfemarem e zombarem dos crentes e a outra, condenada, está pagando suas penas por caluniar e acusar autoridades religiosas e virgens de pecados sexuais: libertinagem e adultério. Como mostro posteriormente, essas duas classes de pecados de língua (blasfêmia, fofoca) e sexuais são os pecados mais presentes nas descrições de Inferno nas fontes em destaque.

A seguir, apresento outra fonte com que este artigo trabalha, o Apocalipse de Pedro.

\section{ASPECTOS RELEVANTES DA OBRA O APOCALIPSE DE PEDRO}

O Apocalipse de Pedro (ApPe de agora em diante) é, segundo Martha Himmelfarb, o texto mais antigo do Cristianismo em que se encontra uma descrição do Inferno. Segundo ela, algumas citações de Clemente de Alexandria localizam essa obra em meados do segundo século. Antes da descoberta, em 1887 de um manuscrito grego do oitavo ou nono século na caverna de um monge em Akhmin, no Alto Egito, o ApPe era 
conhecido apenas por alusões e menções em listas canônicas.(Martha HIMMELFARB, 1983, p 8) Na primeira década do século XX uma longa versão etíope surgiu numa coleção de manuscritos. Há uma discussão, inicialmente sustentada por M R James de que, a versão etíope era mais próxima do original do que a versão grega. James sugere que a versão grega do ApPe foi adaptada para servir como parte do Evangelho de Pedro, outro texto descoberto no mesmo códex da caverna em Akhmim. Ele acredita que a versão etíope tenha sido traduzida mais diretamente (Martha HIMMELFARB,1983, p 11). Além disso, apenas a versão etíope oferece o texto de forma completa. A versão grega é mais fragmentada (Wilhelm SCHEELMELCHER, 2003, p 67).

Alguns textos de Pais da Igreja mencionam o ApPe, e essas menções são importantes para destacarmos o papel exercido pela obra e em algum aspecto, fortalecer os argumentos de sua datação antiga. Citando apenas algumas das obras que mencionam o ApPe temos: o fragmento de Muratori²; Clemente de Alexandria nas obras Hypotoposes e Eclogae Propheticae cita o ApPe por volta do ano 200 EC; o Catalogus Claromontanus, um catálogo oriental das Escrituras Sagradas do século III que elenca o ApPe; Eusébio em sua História Eclesiástica, cerca do ano 339 EC, menciona a obra junto com o Pastor de Hermas, para citar alguns dos mais antigos (Jan BREMMER; István CZACHESZ, 2003, p 25).

Como uma das obras mais antigas em que se pode observar uma descrição do Inferno, o APPe é fundamental para o tema da presença feminina entre as pessoas condenadas por seu aspecto plástico, no sentido de descrições de castigos sofridos nos corpos dessas pessoas serem descritos de maneira muito visual: o texto descreve os sofrimentos dos corpos sendo perfurados, queimados, pendurados e atribui a cada um desses sofrimentos um sentido de causa e efeito, relacionando o castigo com o pecado cometido por cada pessoa.

\section{O APOCALIPSE DE PEDRO}

O Apocalipse de Pedro é a revelação feita por Jesus Cristo a seus discípulos e em especial a Pedro. Todos estão reunidos no Monte das

\footnotetext{
O Fragmento de Muratori é uma lista de escritos sagrados, primeiro publicado por Muratori em 1740, encontrado por ele em um manuscrito do séc VII ou VIII na Biblioteca Ambrosiana em Milão, datado no séc III ou IV.
} 
Oliveiras, onde Jesus está assentado e é questionado pelos discípulos sobre os sinais do fim. Encontra-se nessa narrativa grandes semelhanças com o relato de Mateus 24 e paralelos.

Jesus, como no sinótico, adverte os discípulos contra os falsos Messias que irão surgir, levando muitos ao martírio. Ele então mostra a Pedro, na palma de sua mão direita a imagem do que se cumprirá no último dia: o Inferno se abrirá e ocorrerá uma ressurreição generalizada. A terra será consumida pelo fogo e coberta de trevas. Jesus virá numa nuvem e a punição eterna começará.

Se segue a descrição das punições: alguns pecadores são pendurados por membros específicos de seus corpos como línguas, pés, entre outros. Outros pecadores são imersos em abismos e torturados por bestas. Alguns recebem chamas de fogo. Pedro recebe um vislumbre do futuro dos santos que irão testemunhar o castigo dos pecadores e são transportados para Acherusia (Acherúsia é um lago da mitologia grega de ligação com o mundo inferior), identificado como os Campos Eliseos. A cena final do Apocalipse de Pedro é de Jesus com seus discípulos no monte santo quando eles veem Moisés e Elias com Jesus. Tem-se aqui, uma versão da transfiguração dos Evangelhos (Martha HIMMELFARB, 1983, 8-11).

O ApPe inicia suas descrições de Inferno sem destacar diferenças de gênero entre seus condenados, mencionando pessoas que pagavam penas, penduradas pelas línguas por terem blasfemado. Também apresenta castigos para pessoas que se desviaram, mergulhadas em um lago de lama e assassinos, observados por suas vítimas. Menciona homens e mulheres quando descreve castigos de perseguidores, blasfemadores e ricos que não tiveram compaixão por órfãos e viúvas e pessoas que praticaram a usura e abandonaram o caminho de Deus. Abaixo menciono 3 versos da versão etíope do ApPe encontrada na caverna de Akhmin para dar este destaque e comento a seguir:

24. E haviam também outras, mulheres penduradas pelo seu cabelo, em cima daquele lodo fervente: estas eram as que se adornavam para o adultério; mas os homens que se uniram com elas na corrupção do adultério (estavam pendurados) pelos pés e tinham suas cabeças naquele lodo e gritavam (em voz alta): "Não 
acreditávamos que chegaríamos até este lugar!"

26. E perto daquele lugar vi outro vale para o qual corriam o fluxo e os excrementos daqueles que estavam sendo castigados e se tornaram num lago. E lá estavam sentadas mulheres com os excrementos até seus pescoços e na frente delas estavam sentadas muitas crianças, chorando, que foram por elas, abortadas. E das crianças saiam raios de fogo e golpeavam as mulheres nos olhos. Eram estas que conceberam filhos fora do casamento e procuraram aborto.

32. E outros homens e mulheres que estavam sendo lançados num grande precipício abaixo, chegavam ao fundo e eram levados a subir novamente do precipício por aqueles que estavam colocados sobre eles, e novamente eram lançados para baixo e não tinham descanso deste castigo. Eram aqueles que macularam seus corpos agindo como mulheres; e as mulheres que estavam com eles eram aquelas que se deitaram uma com a outra, como um homem com uma mulher. (Jan BREMMER; István CZACHESZ, 2003, p 41-42).

Nos trechos mencionados acima, o aspecto que chama atenção na descrição do ApPe é a ênfase de protagonismo feminino quando se tratam dos pecados sexuais.no primeiro caso, as mulheres são penduradas pelos cabelos porque se adornaram para o adultério. Chama a atenção o fato de que os cabelos são símbolo da feminilidade das mulheres no mundo judaico-cristão, fazendo com que até mesmo o apóstolo Paulo sugira a utilização do véu entre as mulheres que pertenciam às comunidades cristãs nos primeiros séculos, porque o cabelo era visto como uma identidade da mulher, um dom que elas deveriam preservar para ser mostrado apenas aos seus maridos. Então, o castigo no Inferno, é importante destacar o fato de que a mulher que cometeu adultério estava condenada sendo pendurada pelos cabelos, enquanto os homens que foram seus parceiros nesta prática, estavam pendurados pelos pés.

Na cena seguinte, o protagonismo feminino é evidente, por se tratar do castigo sofrido pelas mulheres que fizeram aborto. Essa é uma das cenas mais fortes da descrição do ApPe. Além das mulheres estarem submersas em fluídos corporais e excrementos, elas são castigadas por demônios em forma das crianças abortadas por elas.

E por fim, a prática homossexual também é descrita no trecho destacado do ApPe com um protagonismo feminino: as mulheres estão 
condenadas por se deitarem com outras mulheres e mesmo os homens apresentados nesse quadro, estão condenados porque "macularam seus corpos, agindo como mulheres".

Entretanto, antes de analisar mais a fundo a ênfase dada nas descrições cristãs primitivas de Inferno, é necessário apresentar a última fonte que serve de base para o debate deste artigo.

\section{ASPECTOS RELEVANTES DA OBRA O APOCALIPSE DE PAULO}

Para apresentar a última fonte, utilizo como base a edição crítica de Theodore Silverstein e Anthony Hilhorst e a tradução em português do texto do Apocalipse de Paulo (Visio Pauli, VP, a partir de agora) de Michele Evangelista, publicada no número 7.12 (2011) na Revista Oracula e parte do comentário de Antonio Piñero, Os Apocalipses - 45 textos apocalípticos apócrifos judeus, cristãos e gnósticos, num lapso de tempo de 600 anos - metade do século 3 AEC até meados do século 3, 4 EC, segundo o autor (Antonio PIÑERO, 2007, p 2). Nesta obra, Piñero apresenta alguns debates a respeito das origens e do porque da existência de textos apocalípticos entre os cristãos em suas origens. Ele defende que os gêneros apocalípticos surgem intimamente ligados ao desejo de libertação que vem se formando no povo em geral e em especial em alguns grupos piedosos. A apocalíptica tem, aos olhos de Piñeiro a ver com esperanças nacionais de salvação e ao conceito de "messianismo" que começa a surgir entre os séculos 3 e 2 AEC em Israel e logo será herdado pelo cristianismo (Antonio PIÑERO, 2007, p 2). Retomo esse assunto, posteriormente.

A VP, defende Piñero, é transmitido em forma tardia, a partir do século 5, mas o próprio autor aponta uma origem anterior ao afirmar que Orígenes no século 3 já cita uma obra chamada Apocalipse de Paulo. Ele aponta também que em sua obra "Contra todas as heresias" Irineu de Lion faz referência a algumas visões de Paulo e portanto, é possível dizer que a VP tenha sido composta antes do fechamento da redação dos escritos de Irineu: em meados do século 2 EC. O texto conservado é uma versão latina mas existem ainda cópias mais fragmentadas em copta, siríaco, armênio e eslavo "eclesiástico" nas palavras de Piñero. O texto original, defende, foi composto em grego. Mas desse original 
só se conserva um amplo fragmento em códice do século 15, editado por C Von Tischendorf (Antonio PIÑERO, 2007, p 7).

Segundo Silverstein, o texto foi originalmente escrito em grego, no Egito e datado por Tischendorf do final do século 4 EC, embora existam evidências de que a obra fosse conhecida pelos cristãos do Egito em meados do século 3 e evidências externas localizam o que ele chama de "primeira edição", algumas formas mais antigas dos manuscritos também por volta do século 3 EC ou mesmo antes. As evidências externas, segundo ele, são os conteúdos do texto em si mesmo, os quais "não estão de acordo com a vida e a linguagem cristãs daquele período anterior”(Theodore SILVERSTEIN,1997, p 4) Por exemplo, as punições que os não crentes recebem nos lugares de tormentos, estão de acordo com princípios básicos da nova fé: negar a ressurreição, a doutrina da concepção virginal e a doutrina de Cristo como Filho de Deus (Theodore SILVERSTEIN, 1997, p 5).

\section{O APOCALIPSE DE PAULO}

O texto consiste do seguinte: descobrimento das revelações feitas a Paulo por meio de um anjo a um cidadão de Tarso; Ascensão de Paulo ao terceiro céu, onde ouve as queixas da criação contra as maldades dos homens; o testemunho dos anjos sobre essas ações e a descrição do juízo divino sobre justos e malvados. A seguir há uma descrição do momento em que as almas de pessoas boas e pessoas más deixam o corpo, na hora da morte e uma descrição do Paraíso. Na primeira parte da VP, Paulo é levado até o terceiro céu, conduzido por um anjo, vê a alma de um santo deixando o corpo e sendo levado até a presença de Deus e depois vê a alma de um pecador deixando o corpo e sendo levada até a presença de Deus para uma última oportunidade de arrependimento. Como não há esse arrependimento, é levada para as trevas. Paulo conhece a Cidade do Cristo, onde é apresentado a Enoque, passa por profetas e ao Paraíso, lugar onde são recebidos os que passaram necessidades no mundo, mas morreram fiéis a Deus. Depois disso, Paulo é levado para conhecer as regiões infernais. Na apresentação do Céu, em três níveis, até o terceiro, não há nenhuma figura feminina em destaque. 
A seguir, o apóstolo é levado por seu anjo-guia ao local onde os condenados sofrem suas penas. Novamente, os pecados castigados são descritos como blasfêmia contra autoridades religiosas, não tiveram piedade por órfãos e viúvas, praticaram usura e pessoas ricas que confiaram em suas riquezas, além de autoridades da Igreja que descumpriram seus votos ou foram desonestos nas práticas de suas obrigações. A VP destaca em especial pecados referentes a autoridades eclesiásticas e não cumprimento de obrigações religiosas, como quebra de jejum ou falta de atenção ao anúncio da Palavra de Deus e cometer pecados depois de participarem da Eucaristia.

Mesmo nos pecados sexuais, não existe uma grande ênfase ou diferenciação, entre homens e mulheres: adúlteros e homossexuais recebem o mesmo tipo de condenação, diferente do que ocorre no ApPe. Para exemplificar, menciono alguns trechos:

Novamente eu vi homens e mulheres com um semblante negro no poço de fogo, e eu suspirei e chorei e perguntei: “Quem são estes, senhor?” E ele me disse: “Estes são os devassos e adúlteros que tiveram suas esposas e cometeram adultério. Da mesma forma as mulheres que no mesmo caminho, apesar de terem seus maridos, cometeram adultério. Portanto, eles pagam estas penas sem cessar".

Eu vi outros homens e mulheres, suspensos por suas sobrancelhas e seus cabelos, e um rio de fogo provocava-os, e eu disse: “Quem são estes, senhor?” E ele disse: "Estes são os que não se dão aos seus maridos e esposas, mas para adúlteros, e, portanto, pagam suas devidas penalidades sem cessar".

Eu vi outros homens e mulheres, cobertos com poeira e suas aparências eram como sangue, e eles estavam em um fosso de piche e enxofre e eram transportados para baixo em um rio de fogo. Eu perguntei: “Quem são estes, senhor?” E ele disse: "Estes são os que cometeram perversidades em Sodoma e Gomorra, homem com homem, portanto eles pagam suas penas sem cessar". (Michelle EVANGELISTA, 2011, p 236)

Como pode ser observado, a VP não criou muitas diferenças nas formas como castigou seus condenados em relação às descrições do ApPe. A obra enfatizou mais pecados religiosos. Ao tratar de pecados sexuais, por um lado, manteve a linha de seu antecessor, por outro, 
não deu maior importância a essas práticas. Contudo, quero destacar abaixo, duas cenas a respeito de pecados específicos cometidos por mulheres no Inferno da Vp:

Lá vi jovens vestidas de preto, e quatro anjos assustadores seguravam em suas mãos e correntes em brasa eram colocadas em seus pescoços e as levaram para longe dentro da escuridão. E novamente chorei e perguntei ao anjo: "Quem são estas, senhor?" E ele disse: “Estas são aquelas que eram virgens, mas perderam sua virgindade e seus pais não souberam. Portanto, elas pagam sua devida penalidade sem cessar" (Michelle EVANGELISTA, 2011, p 237)

Nesta cena, são descritas jovens mulheres vestidas de preto, presas por correntes em brasa e conduzidas por anjos assustadores para dentro da escuridão por perderem a virgindade e esconderam isso dos pais. Não existe uma explicação maior sobre a justificativa dessa condenação, a não ser o fato da prática sexual e a omissão do fato por essas jovens, que provavelmente, o texto deixa a entender, fizeram sexo antes de se casarem. Ao tratar o tema do aborto, a VP mantém a presença dos filhos abortados, mas não mais como demônios que os castigam, mas como espécies de testemunhas de acusação contra eles, diante de Deus. Além de acrescentar a presença dos homens, como os pais dessas crianças abortadas, a VP compara o crime dessas pessoas condenadas a uma categoria religiosa também, de "contaminar a criação de Deus" e "não observar os mandamentos", como pode ser observado no trecho a seguir:

Olhei e vi outros homens e mulheres num espeto de fogo e bestas estavam os dilacerando, e eles não tinham permissão para dizer, "Senhor, tenha misericórdia de nós". E eu vi o anjo dos tormentos colocando o mais feroz dos tormentos neles, dizendo, "Reconheçam o filho de Deus, pois foi dito a vocês antes, mas quando as escrituras de Deus foram escritas para vocês, vocês não deram atenção. Portanto, isto é apenas o julgamento de Deus, pois as suas más ações trouxeram vocês a esses tormentos". Mas eu suspirei e chorei e perguntei: "Quem são estes homens e essas mulheres que são estrangulados neste fogo e pagam suas penas?" Ele respondeu: "Estas são as mulheres que contaminaram a criação de Deus, quando 
arrancaram as crianças de seus ventres e estes são os homens que se deitaram com elas. Mas as suas crianças apelaram para o Senhor Deus e para os anjos que estão sobre os tormentos, dizendo: "Escolham a vingança para nossos pais, pois eles contaminaram a criação de Deus. Eles conheceram seu nome, mas não observaram seus mandamentos." Eles foram dados como comida para cachorros e foram pisados por porcos e outros, e foram lançados no rio. Mas, estas crianças foram entregues para os anjos do Tartarus assim que eles foram trazidos para o lugar de misericórdia, mas seus pais foram rebocados ao tormento eterno". (Michelle EVANGELISTA, 2011, p 237)

Na descrição de Inferno na VP, não existe um demônio feminino, como ocorre no Ato 1 dos AF, mas, assim como no ApPe, as mulheres são destacadas entre as condenadas: mulheres que abortaram, mulheres adúlteras, mulheres virgens que fizeram sexo antes do casamento. E na primeira parte, dos 3 níveis de céu, nenhuma mulher sequer é citada. No inferno, nas regiões das profundezas, as figuras femininas se destacam por seus pecados.

Na parte final da VP, após essas cenas, o apóstolo é levado pelo anjo ao Paraíso, onde encontra os patriarcas das 12 tribos, Abraão, Isaque e Jacó, Ló, Jó, Noé e Moisés e é saudado pela Virgem Maria. Além dessa presença feminina ilustre, outra mulher é mencionada indiretamente neste trecho final: ao descrever o paraíso, a obra menciona que este é o lugar onde Adão cedeu à sedução da mulher.

Como a VP procura enfatizar pecados cometidos contra as estruturas eclesiásticas, as poucas presenças de mulheres destacadas pelas práticas de aborto ou mesmo as jovens que mentiram aos pais sobre a gravidez e as práticas homossexuais acabando conduzindo a esse teor de preocupação eclesiástica. Em todo caso, os poucos destaques dados à presença feminina no Inferno em castigos mais específicos reforçam o entendimento de que a natureza retórica desses textos de descrição de inferno buscam colocar as mulheres em lugares muito específicos entre os condenados pelo CP.

Sobre estas fontes apresentadas, muito se discutiu, ao longo da história da pesquisa, sobre as origens, mas principalmente, sobre os motivos que teriam levado o CP a produzir narrativas sobre os castigos 
sofridos pelos pecadores condenados ao Inferno. Muito se especula e algumas hipóteses são ventiladas. Alguns autores debatem se os cristãos inverteram a lógica e se utilizaram de recursos e mecanismos de tortura que eles mesmos sofreram na perseguição por parte do Império Romano; outros foram pelo caminho de que, os cristãos herdaram e radicalizaram os textos de castigos pela Lei de Talião do Judaísmo do Segundo Templo, em que os membros pecadores devem ser punidos. Em certo sentido, os cristãos teriam radicalizado esse conceito judaico, a partir do sermão do Monte, em que Cristo recomenda que se arranque um olho, se ele te induz ao pecado. Todas essas discussões são levantadas por Martha Himmelfarb e Stvan Czachesz em suas obras.

Nossa hipótese para explicar tais narrativas é a de que os cristãos primitivos utilizaram essas imagens como retórica para, de certa forma, "vingar" ou fazer justiça a algumas práticas com as quais eles discordavam. Além da impossibilidade de ver tais pecadores alcançados pela lei humana, havia no $C P$, essa é nossa aposta, um forte desejo de ver práticas discordantes serem punidas, ainda que essa fosse uma possibilidade reservada apenas para o futuro. Ao mesmo tempo, seguiam o padrão apocalíptico de retórica de uma imagética e de violência nas descrições. Ao se deparar com tais narrativas, os interlocutores precisavam interagir com os sentidos: imaginar as fortes cenas, quase sentir os terríveis odores do fogo e dos fluidos corporais e também as dores descritas pelas torturas sofridas no Inferno para não se aproximarem das práticas inadequadas e ao mesmo tempo, saber que seus praticantes encontrariam seus destinos no Além.

Como o foco neste artigo é discutir especificamente o tema da presença feminina nestas fontes, não gastarei muita energia em debater as origens nem mesmo as motivações para que o CP criasse tais narrativas ${ }^{3}$. Retomo a seguir, uma obra anteriormente resenhada, buscando aplicar os princípios interpretativos nela apresentados: Corpos Apocalípticos - $O$ fim do mundo bíblico em texto e imagem de Tina Pippin.

Para mais sobre este debate, ler: MATTOS, Carlos E. A. Um apocalipse fora de lugar: um relato de viagem ao além-mundo nos Atos de Felipe em comparação com os apocalipses de Pedro e de Paulo. In: RIBLA, n 73. Dossiê Culturas Mediterrâneas 2016/2. 


\section{CORPOS FEMININOS APOCALÍPTICOS: JEZABEL COMO CHAVE DE LEITURA PARA AS MULHERES CONDENADAS}

Tina Pippin apresenta uma leitura de gênero, especificamente do Apocalipse de João, mas defende que toda a literatura apocalíptica é sequencial: Uma obra que segue um outro trabalho e pode ser completa em si e vista em relação ao primeiro e também o que se segue. A história se torna a história sem fim, em versões em constante evolução. $O$ ato de ler é uma continuação de todas as leituras anteriores ((Tina PIPPIN, 1999, p 1) Partindo dessa perspectiva de hermenêutica de recepção, acredito que os pressupostos adotados por Pippin sirvam para a leitura de outros Apocalipses e em especial, a VP também. Ela argumenta que leva a violência do apocalipse a sério, a fim de condená-la, em sua leitura de gênero. Pippin aponta que o fantástico é utilizado ideologicamente nos textos apocalípticos. As histórias dos apocalipses transgridem categorias de "real" e "irreal", de modo que nenhuma tentativa de controlá-los através de qualquer meio interpretativo é totalmente bem-sucedida. O elemento fantástico revela o verdadeiro horror da ideologia. Pippin apresenta o caso da Grande Prostituta no Apocalipse de João: Ela representa o desejo e o desejo é sexual, político, econômico, religioso e então, ela deve ser destruída (Tina PIPPIN, 1999, p 1).

Os apocalipses, antes de textos religiosos, são textos de cultura: a ideologia fortemente exclusivista da profecia apocalíptica é similar ao etos contemporâneo de racismo, sexismo, classismo e outras ideologias

Uma forte imagem utilizada pela autora para representar a perspectiva misógina dos textos apocalípticos é a imagem de Jezabel. Ela aponta a rainha estrangeira apresentada pelos textos bíblicos canônicos como contraditória, controladora e carnal, manipuladora do marido; uma vampira que vaga os textos de cultura e relações de gênero. A autora busca traçar o perfil de "Jezabel" através de vários textos do período bíblico até o presente, usando as teorias da intertextualidade e a construção social do corpo de Jezabel. Começando pelos Livros de Reis e chegando à imagem de uma Jezabel demoníaca apresentada no Livro de Apocalipse 2.20. O caráter complexo e ambíguo de Jezabel na Bíblia serve como a arquetípica vadia-bruxa-rainha nas representações misóginas das mulheres. Jezabel é tomada como arquétipo do mal em 
forma de mulher na cultura bíblica porque prostituição e a fornicação estão associadas a religiões estranhas e à cultura estranha. Nesse caso, a rainha sintetiza toda essa maldade em sua figura e traz consigo os perigos do casamento misto em Israel. Portanto, seu corpo deve ser destruído (Tina PIPIN, 1999, p 35).

A destruição do corpo na morte da Jezabel descrita no livro de Reis é simbólica para os corpos de mulheres condenadas ao Inferno no Apocalipse de Paulo: só sobram crânio; pés; palmas das mãos (2 Rs 9:35). As partes do cadáver de Jezabel são os sinais do corpo liminar, tornados ainda mais limítrofes por se tornarem esterco nos campos. Ninguém é dono deste corpo; como filha de um rei, ela não recebe o enterro apropriado dos cães que a comem. Jezabel, a rainha, agora é Jezabel, a comida de cachorro. Sua carne é devorada. Jezabel como esterco representa a impureza final ( Tina Pippin, 1999, p 38).

Pippins defende que Jezebel é um espaço de fantasia. Ela é um efeito, uma personalidade, um estilo de vida, um modo ético de ser mulher no mundo e uma virada intertextual para o pior. Suas múltiplas histórias são paródias, incluindo a história bíblica ( Tina Pippin, 1999, p 40).

Jezabel retorna eternamente como vampira, o fantasma que viaja pelo tempo assombrando homens e mulheres. Jezabel é a vampira que não pode ser morta, que vagueia por outros textos, tempos e mulheres. Ela tem um futuro de uma forma diferente; ela é constantemente reformada à imagem do desejo e do medo masculinos. Então, é preciso que os Apocalipses de Viagens ao Além continuem destruindo, matando e torturando eternamente ela e as seguidoras de seu exemplo.

A perspectiva apontada por Pippin dessa imagem feminina à luz da rainha Jezabel como sedutora e ao mesmo tempo, monstruosa e perigosa, talvez esclareça uma representação recebida pelos cristãos primitivos do perigo do relacionamento com as mulheres. Contra essas mulheres sedutoras, conhecedoras de feitiços e manipuladoras, a tradição paulina ensina a submissão das esposas aos maridos e os Atos Apócrifos dos Apóstolos narram histórias que enfatizam o encratismo. É necessário se manter longe destas mulheres-vampiras que se rebelam, das quais, o destino é conhecido: os castigos do Inferno. 


\section{LINHAS CONCLUSIVAS}

O céu não parece ser para mulheres. A julgar pelas visões descritas nos Atos de Felipe, no Apocalipse de Pedro e no Apocalipse de Paulo, se existem mulheres no céu, não são muitas. Apenas a Virgem Maria está presente no Céu da VP, presença essa justificada, se concordarmos com algumas pesquisas que apontam o início de sua devoção para meados do século $4 \mathrm{EC}$. Uma única mulher, judia, entre tantos heróis, patriarcas e profetas judeus, num céu cristão. No inferno, podemos afirmar o contrário: o lugar está lotado delas: Mães que abortaram, diaconisas desobedientes, prostitutas, virgens "ansiosas" e esposas adúlteras.

Este artigo não teve como objetivo fazer uma análise sociológica das relações de poder entre homens e mulheres no Cristianismo Primitivo, mas levantou uma suspeita: se os pesquisadores abordados estão corretos, descrições de Inferno serviram como uma forma de revanche narrativa dos primeiros cristãos contra aqueles que representavam perigo à sua fé. Se assim for, tais textos podem revelar quem os cristãos viam como inimigos e como eles imaginavam o pós-morte. No recorte específico proposto por este artigo (a presença feminina no Inferno) a VP nos revela também os perigos que as relações com mulheres representavam para este grupo e é até possível imaginar o que os cristãos esperavam dessas relações. Casamentos (nesse caso, não apenas nos Apocalipses, mas existe também um modelo a partir das narrativas dos Atos Apócrifos dos Apóstolos) e todo tipo de relações sexuais e eclesiásticas.

Embora não esteja no horizonte da proposta deste artigo, é possível perceber como os cristãos primitivos pensavam suas relações com as mulheres das comunidades e o quão temidas essas relações pareciam ser. Seja para reforçar narrativamente patriarcados ou prevenir contra os perigos que mulheres fortes representavam no meio deles, tratar de excluí-las do céu e renegá-las ao fogo das condenações do Inferno foi uma tarefa empreendida pelos primeiros relatos cristãos sobre o Além-Mundo e aparentemente, a julgar pela força narrativa dos escritos cristãos e pelo histórico de opressão às lideranças femininas nos primeiros séculos e mesmo, nos seguintes, logrou grande êxito. 


\section{REFERÊNCIAS}

BAKHTIN, Mikhail. Formas de tempo e cronotopo no romance - ensaios de poética histórica. In: . Questões de Literatura e de Estética. São Paulo: Hucitec/ Anablume, 2010, pp. 211-362.

. A Cultura Popular na Idade Média e no Renascimento: O Contexto de François Rabelais São Paulo/Brasília: Hucitec/UNB, 1999.

CZASCHESZ, István. The Grotesque Body in Early Christian Discourse: Hell, Scatology and Metamorphosis. New York: Routledge, 2014.

EVANGELISTA, Michele. Visio Pauli. A Viagem de Paulo ao Terceiro Céu. In: Orácula Revista de Estudos do Cristianismo Primitivo, v. 7, n. 12, 2011, pp. 235-266.

HIMMELFARB, Martha. Tours Of Hell: An Apocalyptic Form in Jewish and Christian Literature. Pennsylvania: University Of Pennsylvania Press, 1983.

MATTOS, Carlos E A. DEIXAI TODA ESPERANÇA VÓS QUE ENTRAIS: o Inferno na tradição dos apócrifos e sua recepção em textos medievais e contemporâneos. Dissertação (Mestrado em Ciências da Religião). 114f. Programa de Pós-Graduação em Ciências da Religião, Universidade Metodista de São Paulo, São Bernardo do Campo, 2017.

PIÑERO, Antonio. Los Apocalipsis: 45 textos apocalípticos apócrifos, judíos, cristianos y gnósticos. Madrid: Edaf, 2007.

PIPPIN, Tina. Apocaliptic Bodies: The biblical end of the World in text and image. London and New York: Routledge, 1999.

SILVERSTEIN, Theodore, HILHORST, Anthony. APOCALYPSE OF PAUL: A new critical edition of three long latin versions. Geneve: CRAMER Éditeur, 1997.

Submetido em:n 18-12-2019

Aceito em: $13-5-2020$

Mandrágora, v.26, n. 1, 2020, p. 29-47 